\title{
Rational Emotional Behavior Therapy (REBT) to Reduce Anxiety Bullying Victims in Adolescents
}

\author{
Muhammad Erwan Syah ${ }^{1 *}$ \\ ${ }^{1}$ Psychology Study Program, Jenderal Achmad Yani University \\ Special Region of Yogyakarta, 55294, Indonesia \\ *) Correspondent author: muhammaderwansyach14@gmail.com
}

\begin{abstract}
Bullying is an act of hurting others physically and mentally and is done repeatedly. The case of bullying is one of the issues that are still a particular concern at Muhammadiyah Boarding School Al Mujahidin Gunungkidul. This study aims to reduce the anxiety of victims of bullying by using a rational emotive behavior therapy (REBT) counseling approach. The subjects of this study were students of class VII Muhammadiyah Boarding School Al Mujahidin Gunungkidul, who were victims of bullying in classes and schools with a total of 28 students. This research was conducted from August 1 to September 30, 2017. The type and design of the study used collaborative action research. Data analysis was carried out quantitatively using a questionnaire for victims of bullying anxiety. Qualitative analysis is performed on data obtained from interviews, observations, and follow-up. The counseling program with the rational emotive behavior therapy (REBT) approach has proven to be effective and has an effect on reducing anxiety in bullying victims, which is characterized by a decrease in anxiety scores. In addition, the subject feels that he is not alone or not isolated; self-confidence increases have a role towards others and can observe and follow instructions given by the researcher.
\end{abstract}

Keywords: bullying, rational emotive behavior therapy (REBT), anxiety

\begin{abstract}
Abstrak
Bullying merupakan tindakan menyakiti orang lain secara fisik maupun mental serta dilakukan secara berulang. Kasus bullying merupakan salah satu masalah yang masih menjadi perhatian khusus di Muhammadiyah Boarding School Al Mujahidin Gunungkidul. Penelitian ini bertujuan untuk menurunkan kecemasan korban bullying dengan menggunakan pendekatan konseling rational emotive behavior therapy (REBT). Subjek penelitian ini adalah siswa kelas VII Muhammadiyah Boarding School Al Mujahidin Gunungkidul yang menjadi korban bullying di kelas dan sekolah dengan jumlah 28 siswa. Penelitian ini dilaksanakan mulai 1 Agustus sampai 30 September 2017. Jenis dan desain penelitian menggunakan penelitian tindakan (action research) yang bersifat kolaboratif. Analisis data dilakukan secara kuantitatif yaitu dengan kuesioner kecemasan korban bullying. Analisis kualitatif dilakukan terhadap data yang diperoleh dari wawancara, observasi dan tindak lanjut. Program konseling dengan pendekatan rational emotive behavior therapy (REBT) terbukti efektif dan memiliki pengaruh dalam menurunkan kecemasan pada korban bullying, yang ditandai dengan menurunnya skor kecemasan. Selain itu, subjek merasa bahwa dirinya tidak sendiri atau tidak terisolasi, kepercayaan diri meningkat, memiliki peran terhadap orang lain dan dapat mengamati serta mengikuti instruksi yang diberikan oleh peneliti.
\end{abstract}

Kata Kunci: bullying, rational emotive behavior therapy (REBT), kecemasan 


\section{Introduction}

According to the Indonesian Child Protection Commission (KPAI), the case of bullying ranks highest on public complaints. From 2014 to August 2016, KPAI recorded 369 complaints related to the problem, of which only around $24 \%$ of the total complaints in the education sector were 1,475 cases. Bullying forms of violence in schools, defeating student brawls, and educational discrimination (KPAI, 2015). Bullying bad for the victim for example; inferior, ashamed, physically injured, often sick suddenly, feel isolated from the association, academic performance is deteriorating, lack of enthusiasm and fear to go to school even have a feeling of failure when involved in social relations (Erlina, 2016).

Based on the results of the assessment at Al Mujahidin Gunungkidul Muhammadiyah Boarding School, many students from class VII who experienced bullying both full-day and boarding students. Victims of bullying physically complain such as dizziness, migraine, abdominal pain, easy sweating, decreased appetite and some psychological symptoms such as the fear of meeting with bullying perpetrators at the hostel or school, fear of going to school, decreased concentration, reluctance to report to the school or parents about the bullying he receives and withdraws from social relations in the hostel and school.

Schools have given questionnaires to students who have experienced bullying and prevented bullying with psychoeducation, putting up posters that said stop bullying. During this time, the teacher overcomes the problems that occur in the classroom by changing student behavior in the form of rewards and punishments. Also, training on bullying is the give at school, but it is still unable to overcome the phenomenon of bullying that occurs at school. Bullying is one of the issues that are still a special concern at Muhammadiyah Boarding School Al Mujahidin Gunungkidul. Other approaches are more effective in changing children's behavior to be more friendly when in the hostel and at school. The approach is the Rational Emotive Behavior Therapy (REBT) counseling approach. The rational emotive behavior therapy approach is a cognitive-behavioral approach that focuses on individual and group behavior that emphasizes that problematic behavior is caused by irrational thinking so that the handling is individual and group thinking (Komalasari, Wahyuni, \& Karsih, 2011).

Based on the phenomena mentioned above, researchers became interested in researching the handling of bullying victims to reduce the anxiety of victims of bullying in class VII Muhammadiyah Boarding Schools in Al Mujahidin Gunungkidul by using the Rational Emotive Behavior Therapy (REBT) counseling approach in the form of groups. The reason the researchers used the REBT counseling approach was that it could help individuals to change the irrational beliefs of victims of bullying that cause anxiety to be rational beliefs, to have new positive and friendly feelings and behaviors in the dormitory or school (Ghasemian, 2012).

Counseling, according to Prayitno and Erman (2014), is the process of providing assistance conducted through counseling interviews by an expert called a counselor to individuals who are experiencing a problem that boils down to the top of the problems faced by the individual. Accordingly, Winkel (2015) defines counseling as a series of the most basic activities of guidance to help clients face to face with the aim that the client can take responsibility for various problems or special problems.

The word bullying comes from the English language, which is from the word bull, which means a bull who likes to plow to and fro (Wulansari, 2010). This term 
finally taken to describe a destructive action. In Indonesian, etymologically, the word bully means to bully, a person who annoys weak people. The term bullying in Indonesian can use menyakat (derived from the word sakat), and the culprit (bully) is called a donation. Being afraid means disturbing, harassing, and obstructing others (Weinrach, 1995).

Anxiety is a tension, insecurity, a worry that arises because that felt to be experiencing an unpleasant event (Najafi, 2014). According to, Lazarus (1991) that anxiety victim bullying is condition or condition of someone worry and fear of something that has not yet happened that is caused by painful or uncomfortable events due to bullying.

The impacts received by victims of bullying are (Soesetio, 2015), (a) the impact on physical health including headaches, throat, chapped lips, chest pain, and digestive disorders or stomach aches; (b) decreased psychological well-being, when experiencing bullying the victim feels a lot of negative emotions such as anger, resentment, resentment, depression, fear, shame, sadness, discomfort, and being threatened; (c) difficulty adjusting to the environment; psychological disorders such as excessive anxiety, always feeling scared, depressed, suicidal and symptoms of post-traumatic stress.

With group therapy, students will learn social skills and interact with others after group meetings (Ikbal \& Nurjanah, 2012). Rational emotive behavior therapy (REBT) is therapy that is carried out together on individuals and supports individuals making changes in their personalities through methods that directly connect with confronting the mind, explaining how his ideas make them successful., also relates to irrational ideas based on logic, and teaches how to think then encourages individuals to be able to change their irrational beliefs (Hasibuan \& Wulandari, 2015).

This study aims to reduce the anxiety of victims of bullying by using a rational emotive behavior therapy (REBT) counseling approach. According to Ellis (Corey, 2013), rational emotive behavior therapy has support to improve and change students 'attitudes, perceptions, ways of thinking, beliefs and views that are irrational and illogical to make students' views rational, so they can develop themselves, increase selfactualization optimally through positive cognitive and affective behavior. In addition, it makes the classroom atmosphere friendly and eliminates self-destructive emotional disorders such as fear, guilt, anxiety, anger, and anxiety. According to Ellis (Corey, 2013) techniques and procedures carried out in rational emotive behavior therapy (REBT) to make the following class friendly (a) Active-directive teaching; (b) Changing students' way of thinking by discarding illogical ways of thinking; (c) Give assignments to students to try to do certain actions in real situations.

\section{Participant}

\section{Methods}

Subjects of this study were students of class VII Muhammadiyah Boarding School Al Mujahidin Gunungkidul academic year 2017-2018 with a total of 28 students. This research was conduct for two months. They were starting August 1 to September 30, 2017. The researcher collaborates with parents, fellow students, subject teachers, homeroom teachers in designing, implementing guidance programs. In this study using an evaluation program for research while learning in class or boarding. 


\section{Data Collection Technique}

The type and design of the research used in this study use action research. Classroom action research can be interpreted as a research activity to obtain truth and practical benefits by collaborative and participatory action, in this study using two cycles. Collaboration is the collaboration between various disciplines, expertise, and professions in solving problems, planning, carrying out activities, and conducting final assessments. Here collaboration becomes important in classroom action research because one of the characteristics of the class action is the collaboration or collaboration between practitioners and researchers in understanding, agreement on issues, decision making that ultimately gives birth to action (action).

Data collection in this study uses quantitative and qualitative. The quantitative data was collected an anxiety questionnaire on victims of bullying. The qualitative method uses interviews and observations to supplement quantitative data. They have explained that interviewing is a process of direct interaction or communication between the interviewer and the respondent. Data collected can be in the form of facts, attitudes, opinions, desires, or experiences. This study uses a semi-structured interview. According to Sugiyono (2011), the purpose of semi-structured interviews is to find problems more openly, where parties to the interview asked for their opinions and ideas. Researchers in conducting interviews, need to listen carefully and record what is stated by the informants.

\section{Data Analysis}

The observational data of this study were analyzed descriptively to illustrate the state of increasing indicators of success in each cycle and to illustrate success in reducing the anxiety of victims of bullying. The research data collected, after tabulation, are then analyzed to achieve the research objectives. The steps are: (1) Quantitative data the processed using descriptive percentages. The scores obtained are average to find individual successes and classical successes by established indicators; (2) Qualitative data in the form of information in the form of sentences. Data collected at each observation activity from the implementation of the cycle were analyzed descriptively using percentage techniques to see a decrease in anxiety in victims of bullying. follows:

Implementation, observation, and reflection. The description can described as

\section{Planning}

Planning has done at the beginning of each cycle. Planning activities carried out by preparing learning designs, preparing the media and tools needed, as well as instruments can used in research.

2. Implementation

This activity carried out at each meeting in one cycle. The model teacher carries out learning in the form of group services using a rational emotive behavior therapy (REBT) approach to reduce the anxiety of victims of bullying in grade VII students of Muhammadiyah Middle School Al Mujahidin Gunungkidul.

3. Observations

This activity carried out during action. In this case, the collaborator is the observer. Collaborators are guided by observation sheet instruments that have been prepared and prepared in advance. 


\section{Reflection}

This activity is carried out at the end of each meeting and the end of the cycle. Reflections are carried out by the model teacher with collaborators to discuss weak points and more learning points and findings that will utilized to re-plan learning designs in the next cycle.

\section{Findings}

The implementation of the rational emotive behavior therapy (REBT) counseling program to reduce the anxiety of victims of bullying in the fifth-grade students of Muhammadiyah Boarding School Al Mujahidin Gunungkidul odd semester of the 2017-2018 academic year which carried out in 2 cycles, each cycle consisting of 3 meetings namely on August 28 and 4, 11, 13, 16, September 23, 2017. The meeting was in the counseling room and classroom VII B Muhammadiyah Boarding School Al Mujahidin Gunungkidul. Before conducting the research, the researchers conducted preliminary observations. Classroom pre-research activities are conduct to find out the problems that are usually faced by students regarding bullying problems that occur during teaching and learning activities in class.

1. Description of Cycle 1

a. Action Planning

At the planning stage of action including (1) the researcher prepares material by analyzing the problem to find out the problems that exist in the classroom, for this cycle one the researcher prepares material with competency standards to understand the problem about bullying; (2) preparing a service implementation plan (RPL) that will be used by researchers as a reference in implementing the program; (3) prepare research instruments, namely observation sheets, questionnaires, and worksheets. Observations in this study were carried out by two people.

b. Action Implementation

The Implementation Action at the first meeting was held on Monday the 4th, 08.00-08.40 WIB. This research conducted in the counseling room by the researchers themselves as BK teachers. This counseling activity begins with greetings, presentation of the aims and objectives of this research. Besides, researchers also shared and explained about informed consent as an agreement to conduct research. After that, researchers distributed questionnaires to be filled out by research subjects as a pretest. During the rational emotive behavior therapy (REBT) counseling activity, the researcher continues to monitor the activities and activities that occur during the counseling process to obtain evaluation data. The results of the implementation of the first cycle of action, the researcher conduct to observations during the counseling process.In cycle 1, there were 28 students in the counseling process. Based on the results of the bullying anxiety questionnaire data to find out the level of anxiety of the first cycle of bullying victims as follows: 
Table 1 Level of anxiety for victims of first cycle bullying

\begin{tabular}{lrrr}
\hline Range of Percentage & Category & Frequency & Values (\%) \\
\hline $\mathrm{X}<35$ & Low & - & - \\
$35 \leq \mathrm{X}<70$ & Medium & 18 & 64,28 \\
$70>\mathrm{X}$ & High & 10 & 35,71 \\
\hline Total & & 28 & 100 \\
\hline
\end{tabular}

The implementation of Act 2 in Cycle 1 carried out on Monday, September 4, 2017, at the 4th lesson hour, which was 08.40-09.20 WIB. The second study conducted in the counseling room by the researchers themselves as BK teachers. This second meeting began with a group counseling process, then continued with the assignment to fill in the assignment sheet to build hope to foster motivation for victims of bullying when experiencing anxiety. Besides, victims of bullying given the second task of knowing myself to know a picture of myself in the form of strengths and weaknesses.

The implementation of Act 3 in Cycle 1 carried out on Monday, September 11, 2017, at the fifth lesson, which was 09.35-10.15 WIB. The third meeting also held at the same place, the counseling room. Meeting began group counseling reflect incidents, changes occurred victims bullying. In addition, victims of bullying invited to contemplate and think irrational actions according to them to change their thinking patterns to be rational. After counseling, the bullying victims group was given an anxiety questionnaire for victims of bullying to find out progress during the research in cycle 1 . Besides, victims of bullying were also given homework with the aim that they could write down irrational beliefs that had been making them anxious when dealing with bullying perpetrators at school.

a. Observation

The observations found by researchers and observers in the group counseling process in the first cycle, in general, the teacher has carried out counseling activities as planned. Meanwhile, there are some notes for example regarding the use of time used in the research process as there are several classes that are still used the test must adjust the class schedule, group counseling places that are too narrow and the level of involvement and participation of victims of bullying that have not been optimal, such as the attitude of some students who still look less responsive and open to the problem being faced namely bullying. In addition, not all of the research subjects could attend because the subject was permitted when group counseling would held.

b. Reflection

Results of Cycle Actions 1, after completing the action, the researcher and the observer reflect through the analysis of the data from the results of the questionnaire, observation, homework, and existing documentation. This analysis aims to determine the strengths and weaknesses of the group counseling process.

1. Description of Cycle 2

a. Action planning

Based on the results of the reflection of the first cycle which states that some classes are still being used so that they have to adjust class schedules, where group counseling is too narrow, and the level of involvement and participation of victims of bullying has not been optimal, such as the attitude of some students who still look less responsive and open to the problem being faced namely 
bullying. In addition, not all of the research subjects could attend because the subject was permitted when group counseling would be held while the evaluation that has not been able to be achieved even though it is approaching the established criteria is that students as victims of bullying do not want to be open to express what is happening to them when group counseling is taking place. This planning phase researchers and observers prepare a student worksheet, program evaluation, and anxiety questionnaires for victims of bullying. In addition, prepare documentation tools.

b. Action Implementation

The implementation of action 1 in cycle two carried out in class VII B on Wednesday, September 13, 2017, at the 8th-hour class at 11.35-12.15 WIB. The implementation of group counseling in the introduction, researchers, greeting, and opening by saying basmalah then doing relaxation. Researchers explain the flow of implementation in this second cycle so students can understand. After the group counseling opened, the researcher asked each student to tell the changes that occurred in each of them, and what obstacles still made the students anxious when dealing with bullies. After all, students have finished expressing changes and obstacles, and all students asked to fill in the student worksheet, which is the new me. The purpose of my new student worksheet is to know what changes occur in students, plans that must made, and which must abandoned after attending group counseling with the rational emotive behavior therapy (REBT) approach. After all, students filled out the worksheets, the researcher ended with closing and read the hamdalaah and said greetings.

The second action in this second cycle was carried out on Saturday, September 16, 2017, in class VII B, at the 7th lesson at 10.35-11.20 WIB. The second meeting begun with the researcher distributing my new assignment sheet to be read by the owner so that all students could listen to it so that students would dare to express what they felt like victims of bullying. After all, students read the assignment sheet; the researchers conducted group counseling that began with the question of whether there were still those who had not been able to overcome the problem of bullying. After group counseling finished, the researcher closes at this second meeting.

The third action in this second cycle carried out on Saturday, September 23, 2017, at the 7th lesson at 10.35-11.20 WIB. The researcher gave an evaluation in the form of a written test to find out the achievements of students who were victims of bullying in group counseling to reduce levels of anxiety. Based on the results of the bullying anxiety questionnaire data to find out the level of anxiety of the second cycle, bullying victims as follows:

Table 2 Levels of anxiety for victims of second cycle bullying

\begin{tabular}{lccc}
\hline Range of Percentage & Frequency & Category & Values (\%) \\
\hline $\mathrm{X}<35$ & Low & 4 & 14,28 \\
$35 \leq \mathrm{X}<70$ & Medium & 22 & 78,57 \\
$70>\mathrm{X}$ & High & 2 & 7,14 \\
\hline Total & & 28 & $100 \%$ \\
\hline
\end{tabular}

\section{c. Observation}

Observation of the process of group counseling activities with the rational emotive behavior therapy (REBT) approach carried out as in the first cycle, which is assisted by an observer to observe the counseling process. In general, 
researchers have carried out group counseling activities well and as planned, but there are some notes, namely regarding the lack of time for counseling, and there are some people who are permitted when group counseling is in progress so that it disrupts the group counseling process. This is because the two students whose permission did not want to disclose the problem to the researchers and other victims of bullying.

d. Reflection

Results of Cycle Actions 2, after completing the action, the researcher and the observer reflect through the analysis of the data from the results of the questionnaire, observation, homework, and existing documentation. This analysis aims to determine the strengths and weaknesses of the group counseling process. The rational emotive behavior therapy (REBT) approach in this second cycle, finding that most students of bullying victims have felt help to overcome the problems they have experienced, they are also more calm and able to deal when bullies are dealing face to face. However, there are two students as victims of bullying who do not want to be open to express what is happening to them, among the causes are victims of bullying are threatened by bullies so that there is still anxiety in the victims of bullying when opening all the problems to researchers. Below is a comparison of the level of anxiety of victims of bullying in cycles 1 and 2, as follows:

Table 3 Comparison of victims of bullying cycle $1 \& 2$ anxiety levels

\begin{tabular}{|c|c|c|c|c|c|}
\hline Name & Cycle Score 1 & Category & Cycle Score 2 & Category & Description \\
\hline A1 & 77 & High & 68 & Medium & Decrease $(-9)$ \\
\hline $\mathrm{A} 2$ & 75 & High & 69 & Medium & Decrease $(-6)$ \\
\hline A3 & 59 & Medium & 58 & Medium & Decrease $(-1)$ \\
\hline A4 & 67 & Medium & 65 & Medium & Decrease $(-2)$ \\
\hline A5 & 86 & High & 75 & High & Decrease $(-11)$ \\
\hline A6 & 39 & Medium & 37 & Medium & Decrease $(-2)$ \\
\hline A7 & 83 & High & 74 & High & Decrease $(-9)$ \\
\hline A8 & 76 & High & 67 & Medium & Decrease $(-9)$ \\
\hline A9 & 71 & High & 69 & Medium & Decrease $(-2)$ \\
\hline A 10 & 37 & Medium & 33 & Low & Decrease $(-4)$ \\
\hline A11 & 40 & Medium & 37 & Medium & Decrease $(-3)$ \\
\hline A12 & 45 & Medium & 40 & Medium & Decrease $(-5)$ \\
\hline A13 & 38 & Medium & 31 & Low & Decrease $(-7)$ \\
\hline A14 & 41 & Medium & 32 & Low & Decrease $(-9)$ \\
\hline A 15 & 72 & High & 67 & Medium & Decrease $(-5)$ \\
\hline A16 & 51 & Medium & 48 & Medium & Decrease $(-3)$ \\
\hline A17 & 60 & Medium & 51 & Medium & Decrease $(-9)$ \\
\hline A18 & 53 & Medium & 44 & Medium & Decrease (-9) \\
\hline A19 & 54 & Medium & 39 & Medium & Decrease $(-15)$ \\
\hline A20 & 73 & High & 63 & Medium & Decrease $(-10)$ \\
\hline A 21 & 74 & High & 66 & Medium & Decrease $(-8)$ \\
\hline A22 & 64 & Medium & 59 & Medium & Decrease $(-5)$ \\
\hline A 23 & 51 & Medium & 43 & Medium & Decrease $(-8)$ \\
\hline A24 & 65 & Medium & 52 & Medium & Decrease $(-13)$ \\
\hline A 25 & 72 & High & 61 & Medium & Decrease $(-11)$ \\
\hline A26 & 40 & Medium & 31 & Low & Decrease $(-9)$ \\
\hline A27 & 53 & Medium & 39 & Medium & Decrease $(-14)$ \\
\hline A 28 & 61 & Medium & 48 & Medium & Decrease $(-13)$ \\
\hline
\end{tabular}

Based on observations and reflections, the researcher and observer concluded that classroom action research using the rational emotive behavior therapy (REBT) group 
counseling approach was able to be used to reduce anxiety in victims of class VII bullying of Muhammadiyah Middle School Al Mujahidin Gunungkidul. Therefore, this class action research was considered sufficient and ended.

Based on the results of this study indicate that group counseling programs using rational emotive behavior therapy (REBT) approach are proven to reduce the anxiety of victims of bullying. This is known from the decrease in anxiety scores measured using a bullying anxiety questionnaire. The following is a graph comparing the anxiety level of bullying victims in cycle one and cycle 2 .

\section{Discussion}

The findings in this study that majority of students who are victims of bullying feel happy because they are helped to overcome the problems they have experienced, more calm and able to face bullies when dealing face to face. However, there are some students as victims of bullying do not want to be open to express what is happening to them. Meanwhile, the causes are victims of bullying are threatened by bullies so that there is still anxiety on victims of bullying when opening all the problems to researchers. The causes of bullying include a) Family, perpetrators of bullying often come from troubled families, parents who often overly punish their children, or house situations that are full of stress, aggression, and hostility. Children will learn bullying behavior when observing conflicts that occur in their parents and then imitating their peers. b) Schools, because the school often ignores the existence of this bullying, children as perpetrators of bullying will get reinforcement of their behavior to intimidate other children. Bullying develops rapidly in the school environment, often giving negative input to their students, for example, in the form of punishments that are not building so as not to develop respect and respect among fellow school members. c) Peer Group Factors, children when interacting in school and with friends around the house, sometimes are encouraged to bullying. Some children are bullying to prove that they can belong to a certain group, even though they feel uncomfortable with the behavior. Bullying includes intentional acts by perpetrators on their victims (Mishna, Wiener \& Pepler, 2018).

Based on the results of these findings, then further improvements and revisions are made as well as alternative solutions to the problem solving of the various findings to carried out in the second cycle. At the same time, things that support from the first cycle are still maintained and improved in the second cycle.

Bullying includes intentional acts by perpetrators on their victims, which intended to interfere with a weaker person. Individual factors where lack of knowledge is one of the causes of the emergence of behavior, the better the level of knowledge of adolescents about bullying, then can minimize or eliminate the behavior of behavior (Stavrinides, Paradisiotou, Tzigkouros, \& Lasarou, 2010).

The success of this group counseling program shown from the results of evaluations and student testimonials, namely the perceived changes after attending group counseling. This group counseling given using a rational emotive behavior therapy (REBT) approach that makes students feel that they are not alone or not isolated, increased confidence, have a role towards others, and can observe and follow the instructions given by researchers. Besides, there is a positive influence on victims of bullying to improve students' prosocial behavior. Weaknesses and obstacles in this 
research process are the difficulties in arranging the time of the study because they have to ask permission from the teacher when the KBM is taking place, so the researcher must ask permission a week before doing the research. In this study, students who are the subject of research that are not all victims of bullying can go to school because some are permitted being a family event, illness, so that not all research subjects get complete material of the process this research.

\section{Conclusion and Recommendation}

\section{Conclusion}

The anxiety experienced by the research subjects is caused by irrational beliefs that are maintained due to bullying events at school and have not received proper treatment. In a group counseling program with rational emotive behavior therapy (REBT), the approach can reduce anxiety in bullying victims, which is marked by a decrease in anxiety scores. Besides, it makes students feel that they are not alone or not isolated. Self-confidence increases have a role for others and can observe and follow instructions given by researchers.

Decreased anxiety experienced by victims of bullying is shown by their behavior that does not feel excessive worry when meeting with bullying perpetrators, reduced physical complaints, able to avoid perpetrators from being bullied again, able to ignore ridicule or reproach and dare to report to the school or person after being bullied.

\section{Recommendation}

Recommendation for: (1) research subjects, always report to the school when bullied at school or in the dormitory so that they immediately get protection and treatment from the school, avoiding situations that are likely to cause bullying to occur again and often practice positive thinking. Besides, research subjects who have not been able to reveal all the problems that being experienced, so the researchers provide advice for individual counseling; (2) Teachers and counselors, screen victims of bullying using questionnaires and provide psychoeducation to students about bullying. Besides, observing in the classroom and school environment; (3) Schools need to work together in making standardized and strict regulations on school rules, especially regarding bullying and sanctions to obtain protection and comfort.

\section{References}

Corey, G. (2013). Theory and Practice of Counseling and Psychotherapy. Bandung(ID): Refika Aditama.

Erlina, N. (2016). The effect of the rational emotive behavior therapy (REBT) approach on the improvement of emotional intelligence in class VIII students of SMPN 6 Bandar Lampung in the 2015/2016 academic year. Counselee: Journal of Guidance and Counseling, 3(2), 303-316. E-ISSN: 2355-8539.

Ghasemian, D. (2012). Effectiveness of rational emotive behavior therapy on shyness: influence of age. Journal of Psychosocial Research, 7(2), 313-320.

Ikbal, M., \& Nurjanah. (2016). Improving self-esteem by using the rational emotive behavior therapy approach for class VIII students at Muhammadiyah Middle 
School, Jati Agung, South Lampung, 2015/2016 academic year. Journal of Guidance and Counseling, 3(1), 33-46. E-ISSN: 2355-8539.

Hasibuan, R. L, \& Wulandari, L. H. (2015). Effectiveness of Rational Emotive Behavior Therapy (REBT) to improve self-esteem in middle school students of bullying victims. Journal of Psychology, 11(2), 103-110. E-ISSN: 24078786

Komalasari, G., Wahyuni, E. \& Karsih. (2011). Counseling Theories and Techniques. Jakarta(ID): Salemba Humanika.

[KPAI] Komisi Perlindungan Anak Indonesia. (2015). KPAI: Cases of Bullying and Character Education. Accessed May 11, 2016.

Lazarus, R. S. (1991). Progress on a cognitive, motivational relational theory of emotion. American Psychologist, 46(8), 819-834. https://doi.org/10.1037/0003-066X.46.8.819

Mishna, F., Wiener, J., \& Pepler, D. (2018). Some of my best friends' experiences of bullying within friendships. School Psychology Internasional, 29(5), 549573.

Najafi, T. (2014). Theoretical background, therapeutic process, therapeutic relationship, and therapeutic techniques of REBT and CT and some parallels and dissimilarities between the two approaches. International Journal of Education and Research, 2(2), 1-12. ISSN: 2201-6740.

Prayitno, \& Erman, A. (2014). Basics of Guidance and Counseling. Jakarta(ID): Rineka Cipta.

Soesetio, S. R. (2015). Bullying in the eyes of class X high school students: Cognitive manuscripts about the meaning, scenarios, and impact of bullying. Journal of Social Psychology, 12, 1-13.

Stavrinides, P., Paradisiotou, A., Tzigkouros, C., \& Lasarou, C. (2010). Prevalence of bullying among cyprus elementary and high school students. International Journal of Violence and School, 11, 114-128.

Weinrach, S. G. (1995). Rational emotive behavior therapy: A tough-minded therapy for a tender-minded profession. Journal of Counseling and Development, 73(3), 296-300. DOI: 10.1007/s10942-006-0043-0

Winkel, W. S. (2015). Guidance and Counseling in Educational Institutions. Revised Edition. Jakarta(ID): Gramedia.

Wulansari, N. (2010). Dukungan Orangtua dalam Belajar Membaca dengan Kemampuan Membaca pada Siswa Kelas 2 di Sekolah Dasar Bakti Jaya 3 Depok. Skripsi. Universitas Islam Negeri Syarif Hidayatullah, Jakarta. 